\title{
The Physics of Identical Unions and Excitation
}

\author{
Adenugba, D.A. \\ Department of Physics \\ The Federal University of Technology, Akure \\ P.M.B 704, Akure, Ondo State. Nigeria.
}

\begin{abstract}
The Physics of the same sex has been discussed in this paper. Homosexuality and Lesbianism are of this world, fashioned after the carnal lusts of folks of corrupt mind. They are the inevitable products of people with vile imaginations. Looking at homosexuality and lesbianism from the fundamental electric charges and magnetic poles concepts of Physics, we convincingly pointed out that in all ramifications Physics stands stoutly against same sex unions, apart from being condemned by Almighty God. Gayism is going beyond the sexual bond set in marital relationship since the inception of the world by God. An atom that is bombarded with electron will be excited. As excited atom is ground-seeking for stability, so is one who is sexually aroused, craving for sexual release. Sexual excitation and the impacts of sexual thoughts on human activities and acceptable way to release it are addressed. God's immutable reproductive law stands stoutly against homosexuality and Lesbianism. Codes for estimating photon energy, frequency, wavelength, number of electrons per orbital shells and quantum number have been provided. The developed functionalities are exposed in a client package together with the step-by-step workings that will aid real-time teaching and learning. The display of spectral lines caused by electron excitation has also been produced with Microsoft Visual Studio, 2013. It is expected that gays who read this article will drop the practice and embrace the wholesome acceptable way of God-ordained mating and relationship. Newsletters from professional bodies, following the advice given, are expected to include a section on marital relationships for members.
\end{abstract}

\section{General Terms}

Gay, Marriage, Love, Lust, Physics, Sexual thoughts, Sexual tension

\section{Keywords:}

Charges, electricity, excited, homosexual, lesbian, magnetism, Sexual release

\section{INTRODUCTION}

There are two things all Physicists should consider beyond $\mathrm{dy} / \mathrm{dx}$. These two significant parameters are common to all people worldwide. No one, no matter his/her professional calling, escapes the influence and impact of death and sexual tension. The latter is the key focus of this paper; its nature and stout effects on all beings will be adequately discussed. Other objectives are: to discuss sexual thought and sexual release in acceptable way and their influence on human activities. God's scheme of human procreation is discussed to depict gay's indecency, denial of conjugal right and mental aberration. Homosexuality and lesbianism and the related Physics from the perspective of charges, excitation and energy levels will be addressed. Indeed, Physics and sexual excitations will receive sufficient treatment. Magnetic field and flow of electric charges will be utilized to show the emptiness of homosexuality and lesbianism.
A client application to depict various Physics excitation energy levels will be developed using Microsoft Visual Studio, 2013. Functionalities will be provided for photon energy, wavelength and frequency, as well as number of electrons per energy level and quantum number associated with each energy level. Although news of demise of Scientists is disclosed in Scientific Newsletters, there is none on their marital relationship(s). Why and what should be done?

When homosexualist and Lesbianist give up the moral values of God, they yield themselves over to the lusts of the flesh and all kinds of immoral behaviours. Indeed, Roger (2006)[1], correctly observed when he further said, "Homosexuality and lesbianism are the manifestation of corrupted mentalities that are contrary to human sexual behaviour that was ordained by God...In the eyes of God, the Holy Spirit here reveals that in sexual relationships, it is shameful for men to create sexual activity between men and men and between females and females. Homosexuality and lesbianism are the manifestation of a society that has given itself over to the fulfillment of the corrupted lusts of the flesh. As a result of their unnatural sexual activity, they reaped the consequences of sexual diseases.”

Sexual tension is the tension (natural pressure) brought about by the thought of having sexual intercourse with someone. If a male, that someone should be a female and vice versa; any relationship with other person or animal or thing is a sexual perversion. God reveals His mind on this issue in the Holy Bible and in nature.

\section{SEXUAL TENSION}

Sexual sin is the worst of all sins in that it has to do with the entire body and eternal destiny of each person. That is the very reason why Paul counselled the Corinthians: "Flee sexual immorality. Every sin that a man does is outside the body, but he who commits sexual immorality sins against his own body..." (1Corinthians 6:18-20).

Sexual tension disturbs all activities. It gives mental torture. Anyone who is sexually excited is like a leave by flowing river bank. In sexual tension, the heart is taken up completely to have someone to release the tension. The mind works on sex, nothing but sex when the tension is on. It occurs in both males and females. It disregards occupation, race, colours and languages when it is at work. Sexual tension could drive any person to misbehave, commit sexual immorality with any person including underage and harlot. Sexual tension works on the mind and the mind works on the person to act fast to release the tension. It drives; it pushes. Thus, it is unseen force, which effects are visible in behaviour and talk.

Indeed, sexual tension varies in frequency and intensity, depending upon the grace (or self-control) each person possesses. "For I wish that all men were even as I myself. But each one has his own gift from God, one in this manner and another in that. But I say to the unmarried and to the widows: It is good for them if they remain even as I am; but if they 
cannot exercise self-control, let them marry. For it is better to marry than to burn with passion" (1Corinthians 7:7-9). The passion Paul mentions here is sexual tension. As one grows, sexual tension grows. It is closely associated with age. It is natural, thus everybody possesses it, but at different levels. That is the "gift from God, one in this manner and another in that", which marriage is to address satisfactorily. The Pauls of our time with high gift of self-control are to remain unmarried, but without such a gift, go and marry and satisfy your sexual tension (passion).

One of the basic tasks of marriage is to release sexual tension. This is the issue discussed by Paul in (1Corinthians 7:1-6): "Now concerning the things of which you wrote to me: It is good for a man not to touch a woman. Nevertheless, because of sexual immorality, let each man have his own wife, and let each woman have her own husband." By inspiration Paul, who himself did not marry, went further to explain the proper way to release sexual tension. "Let the husband render to his wife the affection due her, and likewise also the wife to her husband. The wife does not have authority over her own body, but the husband does. And likewise the husband does not have authority over his own body, but the wife does. Do not deprive one another except with consent for a time, that you may give yourselves to fasting and prayer; and come together again so that Satan does not tempt you because of your lack of self-control..."

The Devil uses sexual tension to drive people to sin against God. Sexual relationship is difficult to break. This explains why those involved in immoral acts find it hard to cut such sinful relationship. That is also the very reason why couples should be extremely careful not to allow third party to come in-between them. Multiple relationships bring God's displeasure and wrath. Yet those involved in them find it hard to break such relationships; and incur to themselves the severity and eternal punishment of God (2 Thessalonians 1:69).

Paul was clear on how to satisfy individual conjugal right in the family where it properly belongs. By what he said in 1 Corinthians 7 as seen above, couples are sternly warned not to permit Satan to tempt their lack of self-control. Many folks weep to eternity for shunning divine instructions such as the one given in 1 Corinthians 7.

There is time to be in the laboratory and perform breakthrough experiments. But there should be time also to satisfy the home. There is time for everything (Ecclesiastes 3:1-8). Are you abusing and shunning Divine instructions? Since the punishment is severe here and hereafter, you are to heed divine warnings, so that it will be well with you. Sexual tension creates body excitation.

\section{EXCITED STATES}

There are different excited states, two of such states are: Physics and sexual excited states, which are considered in this section. Under the application of external force, the flow of electrons is directed to form electric current, which define two materials: Conductors and insulators. Conductors are materials that permit electric current to flow through them. But insulators do not allow electric charges to flow through them. This could be likened to an impotent person whose body is not charged and excited. Valence shell is the outermost shell of atom and the electron in this shell is referred to as the valence electron. The valence electron experiences less attractive force from the nucleus, so it can easily break off from the attraction of the nucleus upon receiving sufficient energy from outside force [2]. There are three types of impotents (eunuchs or insulators): natural eunuch, man-made eunuch and kingdom-sake eunuch (Matthew 19:12). The first two impotents are sexually unexcited, but the last can still occasionally be excited and with special grace controls his sexual appetite.

\subsection{Physics Excitation}

Excitation, the process of increasing the energy of an atom, is not present in the molecules of a gas. This is because the thermal energy of molecules in a gas is not sufficient to cause excitation. However, upon increasing the energy to higher level, excitation occurs as the atom moves from its present lower energy level to a higher energy level, giving no room for intermediate energy change. Thus, the energy of an atom is discrete. An excited atom is ground-seeking being unstable at the higher energy level. As an atom moves from higher energy state to lower energy level, photon is emitted. This photon carries away the energy lost by the atom in its transition to the lower energy state $[3,4]$; this photon energy (E) is given by

$$
E=h f
$$

In terms of wavelength, $\lambda$

$$
E=\frac{h c}{\lambda}
$$

$\mathrm{h}$ is the Planck constant, $\mathrm{f}$ is frequency $(\mathrm{Hz}), \mathrm{c}$ is the speed of light. This emitted radiation produces spectral lines. The energy that an electron can possess from one energy level to another is quantized. That is, the discrete energy level cannot be continuous over the entire range of the spectral. These energy levels or shells follow a very predictable pattern $[2,3]$. The number of electrons, Ne per each energy level, $n(1,2$, $3 . .$.$) can be obtained from$

$$
N_{e}=2 n^{2}
$$

Using Microsoft Visual Studio, 2013, codes were written for eqns. (1)-(3) and $f$ and $\lambda$. The step-by-step workings that could be employed to learn-teach real-time were dynamically generated. The functionalities were tested by developing a client application for them.

\subsection{Sexual Excitation}

Besides the use of drugs and concoctions, sexual excitation could occur as a result of nudity from the opposite sex, especially the sensitive parts. This is particularly true of a female. But eunuchs, as already noted above, could not be aroused.

Men think women are not stirred up when they expose their body. This is a wrong notion. Women, as human beings, are susceptible to sexual arousal from the men when they expose their body. See-through-clothes are latent weapon of sexual arousal. Through transparent clothes under-wears are made visible, forcing the opposite sex to attempt an act, thinking the one in the see-through-dress is requesting for passion release. This mistaken thought at times leads to rape. Perhaps that partly explains why many ladies are raped nowadays all over the world, since most of them dress with these shameful attires in the name of civilization. 


\subsection{Sexual Thoughts and Sexual Tension Release}

Sexual tension prevents people from praying properly as thoughts are interrupted by sexual thoughts. To be able to pray well with focused mind, there should be release from this sexual thought. Sleep is prevented from closing the eyes as sexual thought reigns in the mind. Sexual thought keeps the eyes wide awake and the mind wanders frantically, seeking for sexual satisfaction. Sexual tension occasioned by the body leads to sexual thought; and sexual thought leads to mental sexual intercourse and other sexual releases.

Sexual tension obscures the sight; lays disgraceful scale on the eyes. That is the reason why most times some folks condescended to the level of engaging in sexual relationships with people below their social status, or things with which such act should not be engaged with. Sexual scale causes semi-blindness or complete blindness. Why, one may ask, is the Permanent Secretary descending so low as to be having unholy sexual affairs with her driver or messenger or houseboy?

Unaddressed sexual thought soils the mind, charged and excited the body to respond in an abnormal way. There are four cases worth mentioning here on how sexual tension and thought are released.

(i) The males masturbate to release sexual tension. The sexual organ is excited in various ways until there is discharge, which causes the sexually excited body to come to the ground state. At this state, restlessness and sleeplessness give way to sound sleep and calmness of the body. The wandering mind come home, lay quietly at rest and is able to pursue things and events in the normal way. Stability that occurs at the ground state is not obtained until the body that is charged and excited emits tension.

(ii) The females also masturbate as they insert their fingers in their private part until discharge occurs. Also, they press their breasts against semi-hard object as though being touched by the opposite sex, and they are highly excited. The ultimate result is mental sexual intercourse; so both male and female engage in mental sex to release sexual tension and sexual thought. The females have the same effects as the males when the tension is released as already pointed out above (i).

(iii) In order to release sexual tension, some people engage in sexual affairs with the same sex type, which God detests. God's specification is heterogeneous sex types (Genesis 2:24; Matthew 19:36), not homogenous sex types. The same sex type when it is between man and man is known as homosexual; and between female and female is lesbian. Paul addressed unnatural love relationship in Romans 1:24-28: "Therefore God also gave them up to uncleanness, in the lusts of their hearts, to dishonour their bodies among themselves, who exchanged the truth of God for the lie, and worshipped and served the creature rather than the Creator, who is blessed forever. Amen. For this reason God gave them up to vile passions. For even their women exchanged the natural use for what is against nature. Likewise also the men, leaving the natural use of the woman, burned in their lust for one another, men with men committing what is shameful, and receiving in themselves the penalty of their error which was due. And even as they did not like to retain God in their knowledge, God gave them over to a debased mind, to do those things which are not fitting." Indeed, nature and acceptable way of sexual release is between legitimate couples. (iv) In an excited sexual state, some people have sexual affairs with animals. God is against such an evil way to release ST and sexual thought. God's approved way to release tension is between a husband and his wife, not wives. In marriage, God wants husband and wife to satisfy their sexual urge or curiosity to the level they desire. Anything outside the matrimonial home is evil in God's sight (1 Corinthians 7:3-5). Also, it should be noted that God did not and does not regard and approve any union between a female and another female; between a male and another male to be marriage.

Show me a Physicist, who does not marry, I will show you a Paul of the Century with uncommon self-control. To marry is not sinful, but to engage in secret affairs is, and to be involved in homosexual or lesbian act is damnation in God's sight. Homosexuality is human invention, thus not divine. Marriage, unlike homosexuality and lesbianism, was created not to gratify human lusts, yes, fleshy lust (Romans 6:12; 13:14; 12:1-2), but to extend the creative work of God through childbearing, and eliminate sexual immorality (Hebrews 13:4). Indeed, marriage is for love and intimate partnership and help (Genesis 2:18; Ephesians 5:22, 33).

\section{ELECTRICITY AND MAGNETISM}

Magnetic properties provide strong evidences that a man and a woman are to be in a love relationship. Over 2000 years ago in China, lodestone (otherwise called "leading stone"), a magnetic iron oxide, was discovered to possess magnetic properties [5]. The second magnet in a natural state is Magnetite also called "iron oxide", (Fe3O4) [6].

Studies had firmly established that like magnetic poles repel, unlike poles attract as figures 1 and 2 gotten from [6, 7] depict.

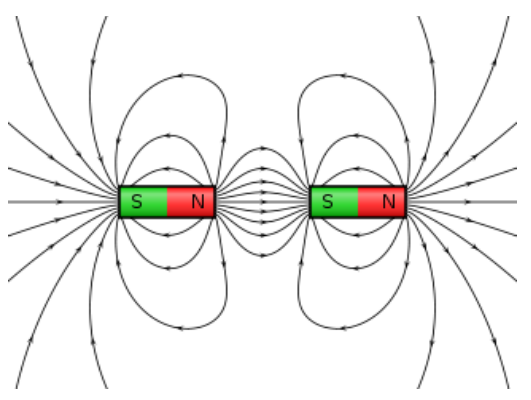

Figure 1: Unlike Poles Attract

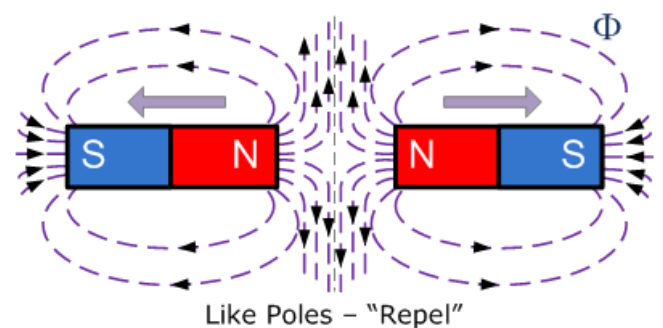

Figure 2: Like Poles Repel

This lodestone is a natural magnet, which Almighty God created on earth to demonstrate and inform humans that heterogeneous objects will attract such as N-S poles; while homogenous one will repel, such as the N-N-Poles and S-S poles. An object often has two unidentical ends like all magnets, which always have North $(\mathrm{N})$ and South $(\mathrm{S})$ poles. Even when cut, magnets still maintain their N-S poles, which when freely suspended point in the directions of their poles. 
Human beings are no exception with a head and two legs. Human properties right from creation depict that the head coordinates other parts of the body; while the legs do the movement. Also, that a man (N-Pole) is to be attracted to a woman (S-Pole) to engage in love relationship is actually and factually entrenched in nature. It is a fact that God created a man and a woman to form intimate sexual relationship, not two men or two women to form any sexual relationship. Has nature altered this in the 21 st century what had existed since the inception of the world? No! Not all!!

A magnet remains a magnet; also, human beings remain human beings, not animals. Human lusts rather than love are at work in the lives of some people, which they endeavour to elevate above the pure work of God. When lust is conceived and nursed, it gives birth to sin. When sin had been fully grown, it gives birth to spiritual death (James 1:15). The earth is unchanged in its dimensions, but lust is seriously gnawing the human inhabitants of the earth to seek shameful things like homosexuality and Lesbianism.

Indeed, the concept of magnet has been in nature since the inception of the world, as well as that of electricity. Positive and negative charges do not repel, but attract each other. That is the way God created the Beings in His image and after His likeness (Genesis 1:26-27). Almighty God in His superior wisdom declared, "Therefore a man shall leave his father and mother and be joined to his wife, and they shall become one flesh" (Genesis 2:24). By this statement, a magnetic declaration at creation, God declared that a positive charge and a negative charge should attract each other; the fact made known by Charles Augustin de Coulomb to the Scientific Community. According to Coulomb: Like charges repel and unlike charges attract.

The strength of the attraction or repulsion is a function of the closeness of the charges or further apart they are. A negative electrostatic charge (electron) very close to a positive electrostatic charge (proton) will experience strong attractive force in their electric fields. The coulomb model shows clearly that less force is experienced when the charges are farther from each other. For two charges $\mathrm{q} 1$ and $\mathrm{q} 2$ at a distance $r$ from each other, the force, either attract or repulsion, is given by

$$
F=\frac{q_{1} q_{2}}{4 \pi \varepsilon_{0} r}
$$

Various experiments have shown Coulomb's principle to be accurate. $\varepsilon_{o}$ is the space permittivity. Closeness brings familiarity and familiarity brings love; love in turn brings intimate relationship that graduates to marriage. The English adage says, "Love is in the eyes of the beholder". It is only the person you behold that you love intimately. Therefore, this proverb supports distance as an element of the strength or weakness of attraction or repulsion.

One principle in programming is: What you see is what you get (WYSIWYG). This useful programming concept informs Software Developers to only present what users should interactive with at a particular time, while other controls are hidden from sight. Let us put this in another way: What you see is what you become familiar with and love (WYSIBBFAL). Similarly, the person you love and marry is a function of your sight and distance. Besides sight and distance, the persons involved in any interaction or relationship are crucial. True love exists between heterogeneous charges (a male and a female) to the exclusion of others. Therefore, there is no interaction between a positively charged atom and another positively charged one. So also, no acceptable interaction between a male and a male, and a female and a female. Indeed, there is no love and marriage between two uncharged beings (two eunuchs) or between a charged (non-eunuch) and uncharged beings (impotent). For emphasis, let it be mentioned again that acceptable human relationship, yes, God-ordained union, exists only between a male and a female.

\section{SCHEME OF HUMAN PROCREATION}

By divine design, a man is an electrostatic positive charge, while a woman (not another man) is an electrostatic negative charge. A man (Adam) was created a full-grown being to advance toward a woman (Eve) created from the ribs taken from the man's sides (Genesis 1:26-31; 2:1-25). It should be noted that God, the able Creator, saw animals that could be helpmate for Adam, but $\mathrm{He}$ did not use that scheme to propagate human beings on earth. By this arrangement, Almighty God, rules out human beings mating with animals. "Whoever lies with an animal shall surely be put to death" (Exodus 22:19).

Also, since man is not the Creator of the universe, he is not qualified to dictates how to advance human procreation and sexual satisfaction. Sexual desires should be from the opposite charges, a male (+) and a female (-). It is an abomination of the first order for sexual desires to be sought and obtained from like charges (a male and a male; a female and a female).

In addition, man was not created to carry pregnancy, be in pains of labour and bear children. This point is supported by Paul's epistle to the young evangelist, Timothy in 1Timothy 5:1-16. Verse 14 reads thus: "Therefore I desire that the younger widows marry, bear children, manage the house, give no opportunity to the adversary to speak reproachfully". Note that it was not men (widowers) but women (widows) who are to bear children. That is, the young widow is to be pregnant from a legitimate male (1 Corinthians 7:37; Romans 7:1-5). Prophet Jeremiah corroborates the fact that pregnancy is the exclusive right of women to carry by this divine statement: "Ask now, and see, whether a man is ever in labour with child? So why do I see every man with his hands on his loins Like a woman in labour, and all faces turned pale" (Jeremiah 30:6). Isaiah talks of pangs and sorrows, as well as pains that take hold of a woman during childbirth (Isaiah 13:8).

Indeed, homosexuality and lesbianism defile the land. Gayism is a man's arrangement, condemned by God right from the Old Testament (OT). It is an abomination! "You shall not lie with a male as with a woman. It is an abomination" (Leviticus 18:22).

Apart from gay marriage which is an abomination to God, mating with animals is also an abomination to the Lord. It is a perversion of the very good creative work of God. "...Nor shall you mate with any animal, to defile yourself with it. Nor shall any woman stand before an animal to mate with it. It is perversion. Do not defile yourselves with any of these things; for by all these the nations are defiled, which I am casting out before you. For the land is defiled; therefore I visit the punishment of its iniquity upon it, and the land vomits out its inhabitants"

(Leviticus 18:23-25). 
Not only is homosexuality and lesbianism condemned in the OT, they stand condemned in the New Testament during this Christian era. Let us turn to the book of Romans which deals with homosexuality and lesbianism. You are enjoined to read the entire chapter 1 , note verses 24-28. Besides desecrating God's creation, it is a mental aberration. No right thinking man, old or young, should advance toward another man in a love relationship meant to satisfy sexual urge or for childbearing. Neither should a properly thinking woman or lady move toward another woman or lady for sexual satisfaction or procreation. Homosexuality, according to Paul's epistle to the Romans, is "against nature." To be modest, homosexuality and lesbianism is nothing but lust, not love. That is aptly described by Spirit-filled Paul as burned in...lust... men with men committing what is shameful". No doubt, homosexuality and lesbianism are disgraceful way of satisfying sexual urge.

Lesbianism is an indecent way to seek childbearing and sexual satisfaction from another woman or lady. Lesbianism is leaving the natural use of the man for that which is uncomely, unacceptable, unapproved by God. Female-toFemale relationship denies men their God's approved right to what is proper and conjugal right. Similarly, a man-to-man love affair denies women their right to what is proper, right and divine scheme of God. Love, yes, decent love, should be between a legitimate male and female.

Right thinking folks in a single voice are saying, No! to same sex marriage all over the world. Homosexuality and lesbianism are regarded as illicit sexual activity [1]. Indeed, homosexuality, as well as lesbianism, is going beyond the sexual bond set in holy matrimony by God. They are abnormal sexual intercourse that questions the pristine sexual setting of Almighty God. Can the clay, of which you and I are one, question the potter? Certainly not!

\section{GO AND MARRY: A THOUGHT FOR SCIENTIFIC NEWSLETTERS}

A reasonable number of scientific newsletters we know publish news of demise of colleagues. This is very nice and good as it helps the living to know what the deceased achieved before kicking the bucket. It is, of course, a good motivation to work harder to meet and/or beat existing records. However, the news of colleagues wedding is conspicuously omitted. Is this an oversight? Is it unscientific? Or should Scientists' marital lives be hidden? While commending, if any, newsletters publishing marital news of professional colleagues, we wish to observe that:

a. It is not out of place to publish wedlock news of colleagues, especially for younger colleagues as a means of motivation to marry and marry the right person.

b. A section indicating a "free election" or a "valence election" free from the attraction of the parents (the nucleus), wishing to marry opposite charge, which has God's divine approval (Genesis 2:24); Christ assertion (Matthew 19:3-12); and apostolic confirmation (1Corinthians 7:1-9), should be given a notable place in the newsletters.

This advertisement section will not only help colleagues to get the right sort of person, it will stoutly motivate the charming electron to occupy the "lattice void" and bring about the completion required in a man and a woman relationship; not in a man-to-man, or a woman-to-woman union where there is no true sexual completion and satisfaction. All Physicists who have not married should do so with the right partner. If you are a man, seek the beautiful electron to make you happy; and if a female, look for the handsome lattice void to fill your life with joy.

\section{DISCUSSIONS}

A home that pleases God, according to Brad [8], is monogamy to the exclusion of polygyny, polyandry and homosexuality and lesbianism. "The Creator did not present Adam with a choice between Eve and another male companion-He made only woman. Adam was not incomplete simply because he lacked human companionship; he lacked female human companionship. Further, the Word of God categorically condemns homosexual behaviour..." Homosexuality is a condemned human concept that deviates from one flesh pattern of Matthew 19:4-6, which God enacted at creation and which Christ reaffirmed while on earth.

Marriage as God wants it distinguishes between two sexes: a male and a female, which is lacking in homosexuality and lesbianism union. Reverence for, and fellowship with God consists in obedience to His Commandments (John 14:15; 15:14-15), which the gays disregarded. There is no home in a union between a male and a male or a female and a female. Home, which is the bedrock of nation building, is firmly established between a marriageable male and a marriageable female; any other set up is a perversion of God's plan and a clear deviation from the original plan of God for the home.

"The home is humanity's primary centre for religious and moral instruction" [8]. "In our homes, we mould good characters. With good characters, we shape our society. And with our society, we shape and build a strong nation" [9]. Within homosexuality and lesbianism union, there can never be a true union as intended by God from creation for home. Since there is no true home in homosexuality and lesbianism, there is no "religious and moral instruction", as well as parents-children relationship in it. True home relationship is only found at home established according to God's will. "A home established with saliva", the Yorubas aptly said, "will come to ruin at the touch of the dew." Homosexuality is such a phoney "home", eagerly waiting its destruction as the hot displeasure of God is poured on it soonest.

The "curse of social disease pandemics as HIV/AIDS" [9] is inbuilt in any relationship outside wedlock. God did not establish a union between a male and a female to produce sexual diseases. When men deviate from the proper and right way God wanted conjugal bliss to be enjoyed in a family, the home suffers for it. It is improper for a man, for instance, to make love to his legitimate wife with the mouth, the so-called oral love or oral sex, which should have rightly been tagged oral lust. Where there is oral lust, there is bound to be sexual diseases; and soon, disaffection.

"The state of the nation is a reflection of the state of its homes" [8]. Roger(2004)[9] succinctly puts quality nation building this way: "Nation building is accomplished through character building...Good families produce good citizens for every community...Any nation that seeks to be united on the foundation of moral living must first encourage the development of solid family structures within society". The family is the indispensable focal point of national growth, development and moral uprightness. The home is an institution with assigned duties and responsibilities, which if faithfully carried out, will result in virile and responsible nation.

The foundation of the nation thus is the homes between heterogeneous human beings. Identical sexual union is not a home; hence it is not a building block for the nation building. 
Rather same sex union, a lustful union that fulfils the lustful desires of the flesh, has a tragic end of everlasting destruction. Just as homes are the reflection of the state of the nation, so are homosexuality and lesbianism the reflection of moral decadence of the citizenry and how deep-necked they are into Sodomite and lusts of the flesh. Since homosexuality and lesbianism do not form a home or a family, their permission in the society will breed citizens of deprave minds and folks of faulty sexual relationships. Formulation of good character starts right from the home; and since homosexuality and lesbianism unions do not produce a home, there is no formulation of good character in such a sinful union. Indeed, good character will not only determine the future, it will equally make the best of bad situation [9].

Water may reflect objects, but it does not look at itself by flowing back as it flows down. That is why it is said by the Yorubas that, "Water that flows never looks back." It has to complete its cycle mandatorily; that is the work of nature, unalterable by man's presence and schemes on earth. Similarly, man never reproduces by looking at himself. Thus, man-to-man union (or female-to-female) or mating is unsupported by nature. It is an outright sexual perversion, condemnable by God and sound human reasoning, logic and realty.

Anarchy and extinction are not far from any society that permits homosexuality and lesbianism to thrive. This evil should be dealt with decisively in order to build and maintain the nation in path of development and positive advancement. Apart from developing parental skill required to establish and develop healthy families [9], God's word should be honoured above our choicest food and games. A person who regards God's word will walk without stumbling (Psalm 119:105); will think purely and positively and be shielded from evil and harms(Proverbs 30:5; Philippians 2:8) and will seek and maintain peace and harmony toward sound family relationship that brings about enhanced and healthy national growth.

Great nations are the products of marital unions between legitimate males and females; and never between males and males, females and females. There is no dignity in same sex union; a union that erodes true home love and destroy good characters and social morality. "Great nations are the result of dignified individuals who seek to dwell together in peaceful unity that is based on the moral integrity of all citizens" [9].

Homosexuality betrays grubby, impure heart and mind and life of the homosexualist. It is nothing other than "wanton sensuality" [1], which openly and widely plagued humanity in this 21 st century. Like homosexuality, lesbianism, is an open lewdness and indecent way of life. God decried this sexual perversion as seen in Leviticus 18:22-25. A legitimate manwoman relationship in holy wedlock will promote genuine love, close intimacy, true companionship, honour and eliminate sin from conjugal union (Hebrews 13:4; Ephesians 5:22-33).

Proper dressing is the necessary and required way to curb sexual excitation, sexual harassment and frequent cases of rapes in our societies. Decent dressing prevent under wear from being exposed and stemmed down improper sexual stimulation.

\subsection{Numeric Estimation}

The Equation main menu of figure 1 has six submenus. This main menu is provided to give users quick access to the models while teaching or learning real-time. When the first submenu is clicked, we obtain this result for frequency, $\mathrm{f}$ :
Frequency, $f=E / h$

Where: $E=$ Energy, $h=$ Planck Constant

After showing the equation, the variables are defined. Other models could be displayed the same way.

From equations(1)-(2), photon energy, E could be computed for given frequency, $\mathrm{f}(\mathrm{Hz})$ and wavelength, $\lambda(\mathrm{m})$; and $\mathrm{f}$ and $\lambda$ could in turn be calculated given E. Frequency and wavelength can only take positive values. We reject zero and negative value before calling a function to compute result based on user's specification via a four-member enumeration class. When dvEhcL member is specified, for instance, under Computations main menu of the screenshot of figure 1 by calling a method, we obtain this result:

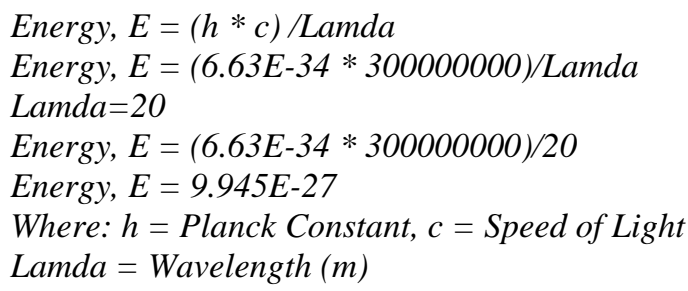

Similarly for eqn. (3), the number of electrons per orbit, $\mathrm{Ne}$ could be obtained via a method called through a submenu under Computations main menu to yield:

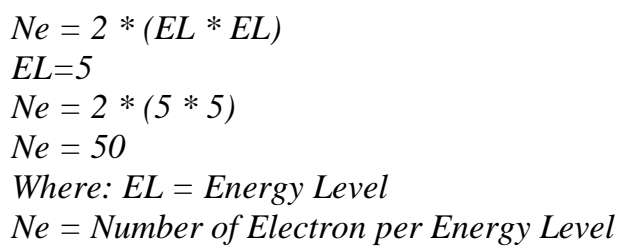

The workings are generated internally by showing the model first; then supply value(s); and then substitute the value(s) one after the other before showing the final result. This good design will assist both tutors and learners to use this Application with absolute ease, with added benefits of being able to persist results by clicking Copy, Save and Print menus, which become visible only after successful computations. Other results were also obtained for $\mathrm{f}$ and $\lambda$. Comparison of results with Excel Package shows that they are identical, confirming the accuracy of our codes.

\subsection{Spectral Lines}

When Spectral Line main menu of figures 1-5 is clicked, four submenus are shown, which in turn have three submenus. These common submenus are:

(i) No Labels. Horizontal lines will be drawn to the specified supply number (here, it is 7) by calling a method.

(ii) Labels. As in (i). Besides, the supply energy texts (E1-En) will be attached to the right of the horizontal lines drawn. If none is supplied, then internal ones are generates to correspond to the number of horizontal lines drawn. If the supply ones fall short of the horizontal lines drawn, additional text will be generated to make up for the deficit. See figure 1 to view the energy levels, E1-E7 without quantum number.

(iii) Label + Quantum number, n. As in (ii) above. More so, $n$ will be attached to the text to depict $n$ values for each energy level. See figure 2 to view the attached $n$ values for each energy level.

The result of clicking Absorption submenu under Spectral Line main menu is shown in figure 3 for (ii) specification. The arrows are pointing upward. When Emission submenu is 
clicked, figure 4 is obtained with the arrows pointing downward for (iii) specification. Figures 1-4 are exaggerated for photon energy, E > 5. To actually depict the compression beyond $\mathrm{E}>5$, a method is called to yield figure 5. Brief note is attached to the absorption and emission spectral lines displayed.

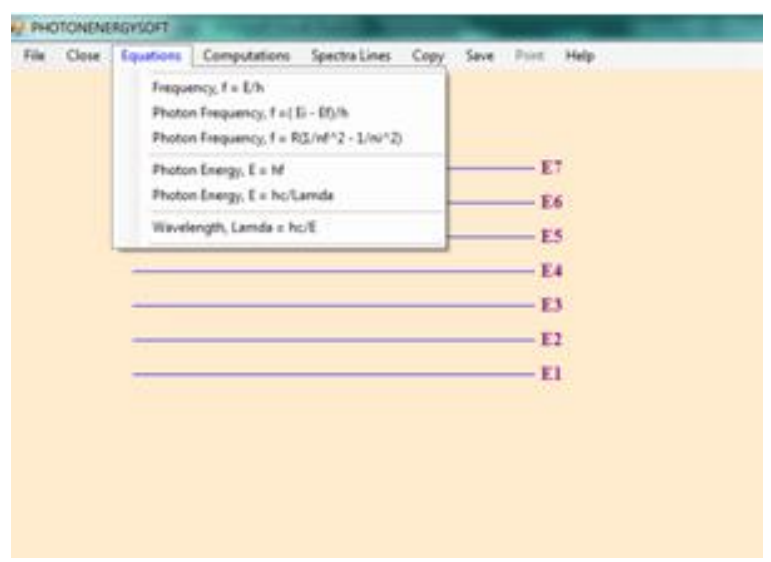

Figure 1: Labelled Energy levels, orbital No not shown

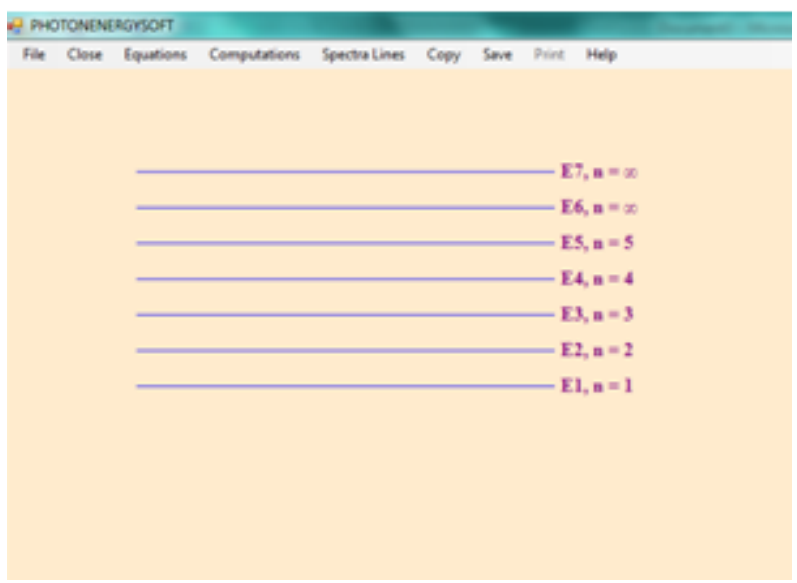

Figure 2: Labelled Energy levels, orbital No shown

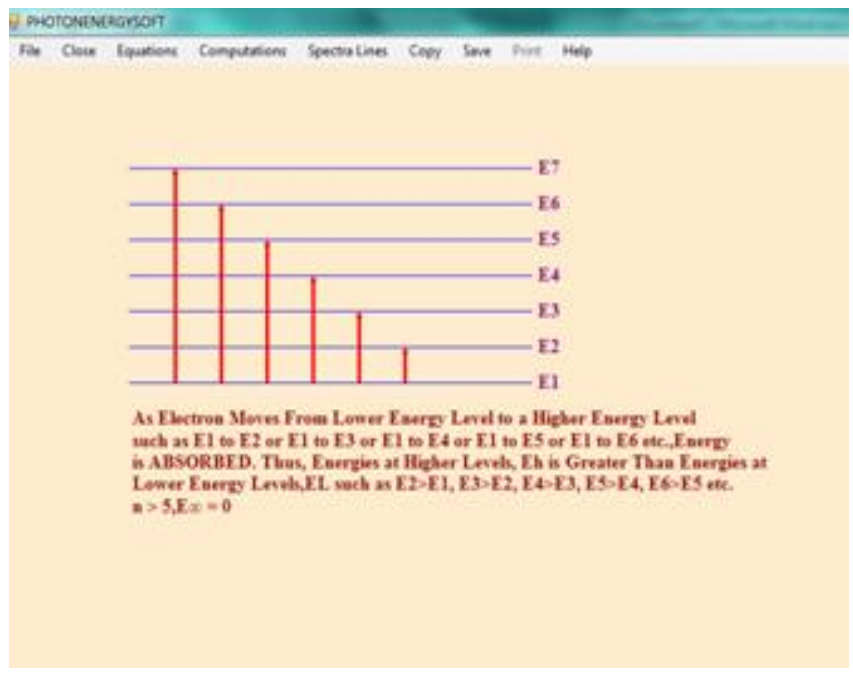

Figure 3: Absorption Spectral Lines; arrows pointing upward, indicating transition from lower energy level to higher energy level

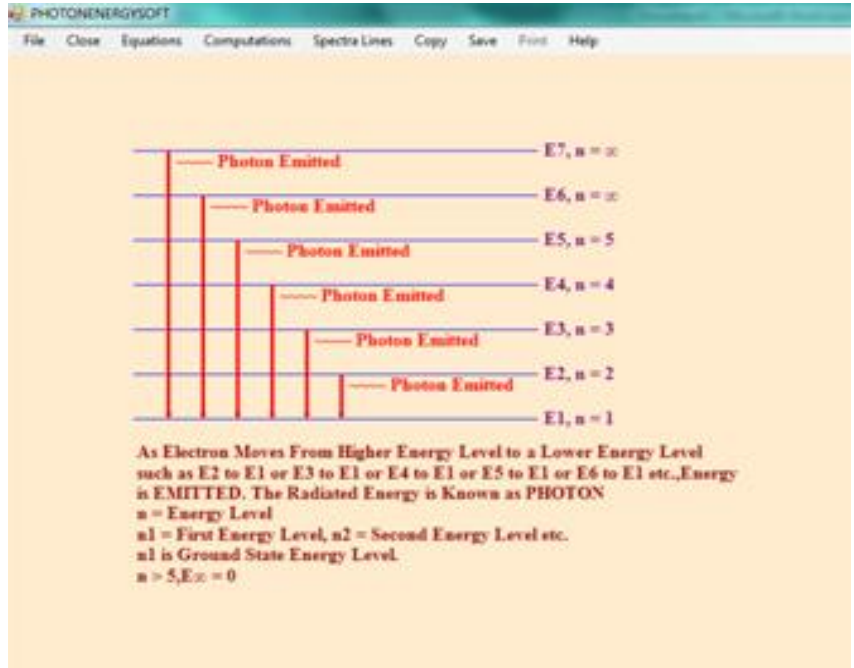

Figure 4: Emission of Photon; arrows pointing downward, indicating transition from higher energy level to lower energy level

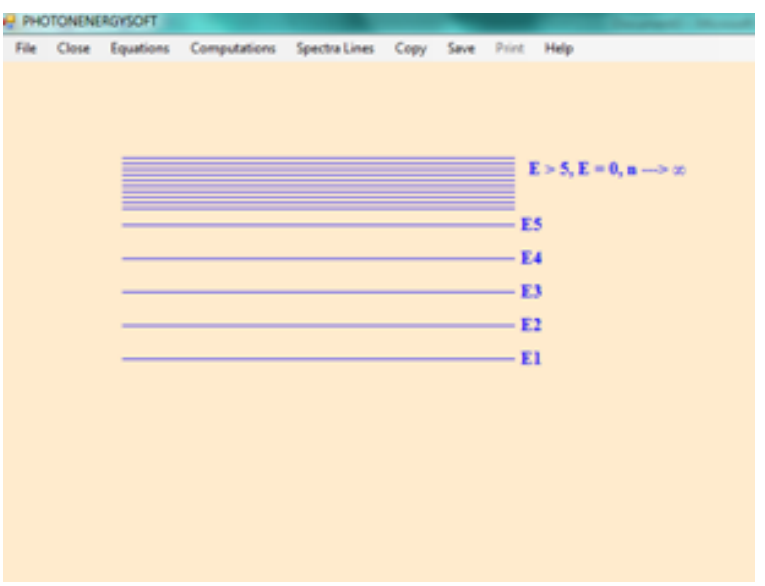

Figure 5: Compressed Spectral lines when $\mathbf{E}>5$

\section{CONCLUSION}

Every living soul, with the exception of eunuchs, is a sexually excited being. The right and acceptable place for sexual release is within marriage. Homosexuality and lesbianism are inevitable products of people with vile imaginations and the ultimate end is eternal damnation (2Thessalonians 1:7-9). A husband who abandons his conjugal obligation to his wife is a failure. The wife who, for one flimsy excuse or the other, shuns her husband conjugal right is unloving. To be carnally minded is homosexuality and lesbianism, but to be spiritually and obediently minded is to marry a woman, if a man; and a man, if a woman (Romans 8:6). Sexual tension does not distinguish between colours and genders. Black and white folks are excited; as it occurs in females, so it does in males; the level, intensity and frequency may vary.

Homosexuality and lesbianism are against the magnetic poles concept of Physics, as well as electricity charge principles. What is right and acceptable to God and the Physics community is: unlike charges attract (a male and a female), like charges repel (a male and a male or a female and a female). Like poles repel, unlike poles attract. Magnetic poles and electric charges are convincing proofs that homosexuality and lesbianism are lewdness, lust of the flesh, gratification and depravity of mind. 
Physics principles in all their ramifications strongly support heterogeneous $(+,-)$ charge attraction and homogeneous charge $(--,++)$ repulsion. Thus, Physics does not support homosexual and lesbian marriage. Gayism is an outright perversion of God's divine scheme to advance human creation through a male and a female. Gay marriage is an abomination, unsupported by nature and a detestable union to God and right thinking human beings.

Codes for the calculation and step-by-step generation of workings for photon energy, frequency, wavelength, number of electrons per orbital shells and quantum number have been provided, which will aid real-time teaching-learning. Using Microsoft Visual Studio, 2013, the dynamic display of spectral lines caused by electron excitation has been produced, which will stimulate interest in Atomic and Nuclear Physics teaching-learning.

There is need to include series in this work, and animate them. Provision of additional notes is required to make our client Application a full-fledge one for teaching and learning. More excitations should be identified and discussed.

\section{ACKNOWLEDGMENT}

Scripture taken from the New King James Version. Copyright (C) 1982 by Thomas Nelson, Inc. Used by Permission. All rights reserved.

\section{REFERENCES}

[1] Roger Dickson (2006). Dickson Teacher's New Testament. Africa International Mission. Commentary on Galatians. Pp. 576-617.

[2] http://www.ndt-ed.org/EducationResources/ Highschool/ Electricity/electriccharge.htm

[3] Federick .J Bueche and Eugene Hecht (2006). Theory and Problems of College Physics Schaum's Outline Series. McGraw-Hill. 10th ed. Pp 398-424

[4] Henry Semat and John R. Albright (1972). Introduction to Atomic and Nuclear Physics. Holt, Rinehart and Winston, Inc. Great Britain. 5th ed; Pp. 256-308

[5] Nelkon, M (1978). Principles of Physics. CSS Bookshops and Hart-Davis Educational. 7th ed., Pp. 572602

[6] http://en.wikipedia.org/wiki/File:VFPt__ cylindrical_ magnets_attracting.svg.Accessed February, 2014.

[7] http://en.wikipedia.org/wiki/File:VFPt__ cylindrical_ magnet_thumb.svg. Accessed February, 2014.

[8] Brad Bromling (date not given). As Goes The Home... www.apologeticspress.org. Accessed 2012.

[9] Roger Dickson (2004). Adventures in Life. The Adventures of Life Foundation. Pp. 3-79. 